\title{
Temporal Variation of Carbon-14 Concentration in Tree-ring Cellulose for the Recent 50 Years
}

\author{
Yoshimune Yamada, ${ }^{* a}$ Kaeko Yasuike, ${ }^{a}$ and Kazuhisa Komurab \\ ${ }^{a}$ Faculty of Pharmaceutical Sciences, Hokuriku University, Kanagawa-machi, Kanazawa-City 920-1181, Japan \\ ${ }^{\mathrm{b}}$ Low Level Radioactivity Laboratory, Kanazawa University, Nomi-shi, Ishikawa 923-1224, Japan
}

Received: June 6, 2005; In Final Form: August 7, 2005

Concentration of organically-bound ${ }^{14} \mathrm{C}$ in the tree-ring cellulose of a pine tree grown in Shika-machi, Ishikawa prefecture, Japan $\left(37.1^{\circ} \mathrm{N}, 136.5^{\circ} \mathrm{E}\right)$, was measured for the ring-years from 1949 to 1999 and compared with those in several trees from East Asia region reported by other researchers. The difference of $\Delta^{14} \mathrm{C}$ values was found during the period of 1970-1981 between our data and those of other reports, in addition to the difference during the period of 1963-1967 caused by the so-called latitude dependence of the ${ }^{14} \mathrm{C}$ variations in the northern troposphere. These results suggest that the ${ }^{14} \mathrm{C}$ concentration in atmospheric $\mathrm{CO}_{2}$ was considerably disturbed during the period of 1970-1981, especially in 1970, 1976, and 1978-1981, in the East Asia region. This phenomenon may be interpreted by the possibility of the several times of injections of ${ }^{14} \mathrm{C}$ originated from a series of Chinese thermonuclear bomb tests.

\section{Introduction}

Most of environmental ${ }^{14} \mathrm{C}$ originates from the continuous production by cosmic rays in the upper atmosphere and from thermonuclear bomb tests carried out during the 1950s and early $1960 \mathrm{~s}^{1-3}$ as well as the case of environmental tritium. ${ }^{4}$

The long-term variation in environmental ${ }^{14} \mathrm{C}$ concentration at the specific site is preserved in the ${ }^{14} \mathrm{C}$ records in a series of annual rings of the tree grown there. ${ }^{5-13}$ Measurement of ${ }^{14} \mathrm{C}$ in the cellulose fraction of tree rings is a preferred method for the analysis of annual variation of ${ }^{14} \mathrm{C}$ concentration, since organically-bound carbon in the cellulose undergoes no change following the time of tree-ring formation.

In the previous paper, ${ }^{9}$ the ${ }^{14} \mathrm{C}$ concentration in the tree ring cellulose of an 80-year-old pine tree grown in Tatsunokuchimachi, Ishikawa prefecture, Japan $\left(36.4^{\circ} \mathrm{N}, 136.5^{\circ} \mathrm{E}\right)$ (hereafter the Tatsunokuchi-sample) was reported for the period of 1941-1987. An interesting fact was that there was a difference in the amplitude of the ${ }^{14} \mathrm{C}$ concentrations between our result and those of other researchers during the period of $1963-1967$, though the year of two peaks in our result coincided with those in the known ${ }^{14} \mathrm{C}$ concentration patterns in the tree rings. ${ }^{5-7}$ The difference may be interpreted by the socalled latitude dependence of the ${ }^{14} \mathrm{C}$ variations in the northern troposphere, ${ }^{1-3}$ which was due to the ${ }^{14} \mathrm{C}$ released to the atmosphere at higher northern latitudes by a series of thermonuclear bomb tests carried out during the 1950s and early 1960s.

In the present work, the ${ }^{14} \mathrm{C}$ concentration in the tree-ring cellulose of a pine tree grown in Shika-machi, Ishikawa prefecture, Japan $\left(37.1^{\circ} \mathrm{N}, 136.5^{\circ} \mathrm{E}\right)$ (hereafter the Shika-sample), was measured for the ring-years of 1949 to 1999 , and the results were compared with those of the Tatsunokuchi-sample to study regional differences in environmental ${ }^{14} \mathrm{C}$ concentration. Shikamachi is located at little higher latitude than Tatsunokuchimachi, as shown in Figure 1.

Furthermore, the annual variation of ${ }^{14} \mathrm{C}$ concentration obtained from the Shika-sample was compared with those of ${ }^{14} \mathrm{C}$ concentration in tree rings from East Asia region reported by other researchers.

*Corresponding author. E-mail: yo-yamada@hokuriku-u.ac.jp. FAX: +81-76-229-2781.

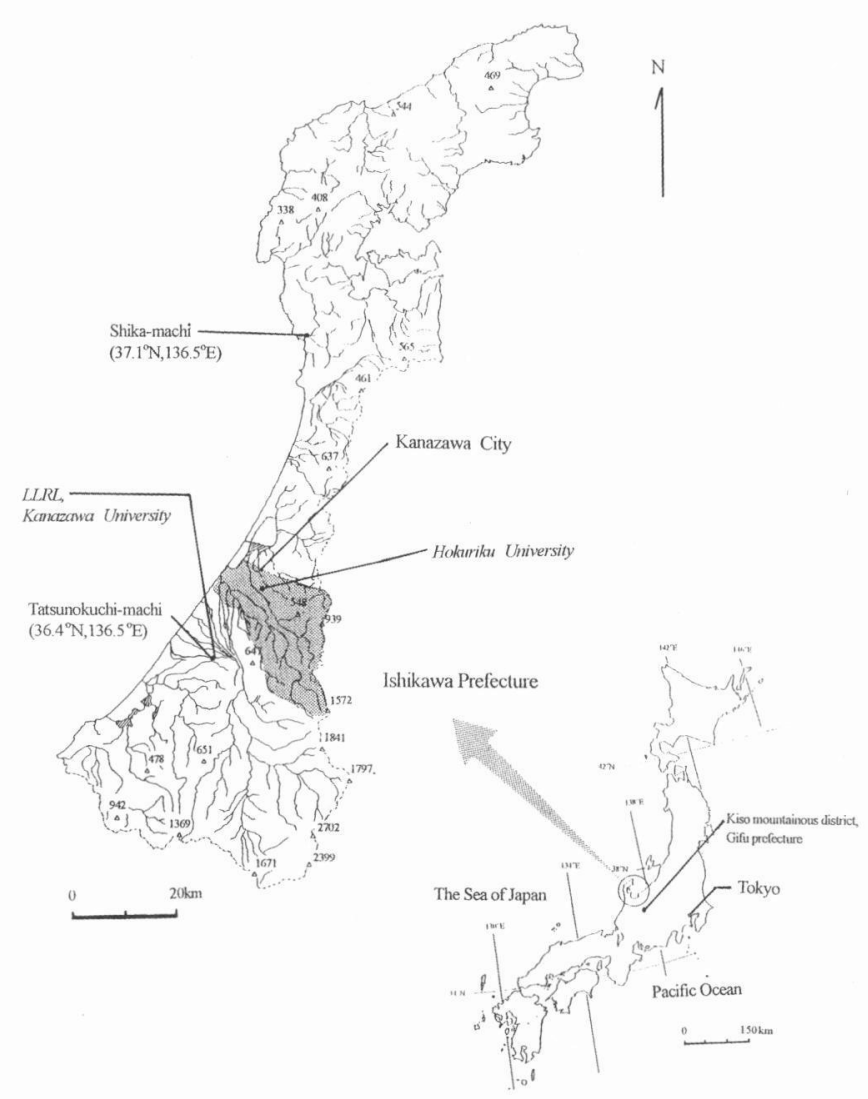

Figure 1. Sampling sites of the pine trees for ${ }^{14} \mathrm{C}$ measurement, Shikamachi, Ishikawa prefecture, Japan $\left(37.1^{\circ} \mathrm{N}, 136.5^{\circ} \mathrm{E}\right)$ and Tatsunokuchimachi, Ishikawa prefecture, Japan $\left(36.4^{\circ} \mathrm{N}, 136.5^{\circ} \mathrm{E}\right)$.

Fine lines in the figure represent rivers in Ishikawa prefecture, Japan.

\section{Experimental}

Cellulose samples of tree rings. The trunk of a 67 -yearold pine tree (Japanese Black Pine; Pinus thunbergii), $0.5 \mathrm{~m}$ in diameter, and $1.2 \mathrm{~m}$ in length, was cut at the position of 0.5-1.7 m above the ground surface on August 10, 1999, and was analyzed in the present work. The pine tree is the same tree used for tritium measurement in the annual growth rings by the present authors, previously. ${ }^{14}$ 
All of the tree-ring layers had a thickness of more than 1.5 $\mathrm{mm}$, which was enough to separate without cross-contamination from subsequent years. Each cellulose fraction corresponding to the 1949-1999 ring-years was isolated from wood chips according to the same method without pre-treatment by the steam explosion of wood chips ${ }^{15}$ which was applied to the Tatsunokuchi-machi tree (Japanese Red Pine; Pinus densiflora).

Combustion of cellulose samples. The cellulose fraction of $100 \mathrm{~g}$ corresponding to a single year was gently burned to obtain the combustion water and $\mathrm{CO}_{2}$ by the method described previously. ${ }^{9}, 14$ The combustion water was condensed in two dry-ice traps connected in tandem. The carbon dioxide gas was collected as dry-ice form by an EtOH trap cooled with liquid nitrogen located behind the dry-ice traps. The resulting dry-ice was immediately converted to calcium carbonate according to the following procedure. A stream of $\mathrm{CO}_{2}$ generated from the dry-ice was trapped by bubbling in a $7 \mathrm{M} \mathrm{NH}_{4} \mathrm{OH}$ solution, and the absorbed $\mathrm{CO}_{2}$ was precipitated quantitatively as $\mathrm{CaCO}_{3}$ by adding an excess of $\mathrm{CaCl}_{2}$ to the solution followed by heating. Approximately $280 \mathrm{~g}$ of dried $\mathrm{CaCO}_{3}$ obtained from $100 \mathrm{~g}$ of cellulose was stored in an airtight vessel.

Benzene synthesis for the preparation of ${ }^{14} \mathrm{C}$ counting sources. The original $\mathrm{CO}_{2}$ was regenerated by adding a solution of perchloric acid dropwise to the $40 \mathrm{~g}$ of stored $\mathrm{CaCO}_{3}$. It was then converted to benzene in vacuum through the following reactions.

$$
\begin{aligned}
& 600{ }^{\circ} \mathrm{C} \\
& 2 \mathrm{CO}_{2}+10 \mathrm{Li} \rightarrow \mathrm{Li}_{2} \mathrm{C}_{2}+4 \mathrm{Li}_{2} \mathrm{O} \\
& \mathrm{Li}_{2} \mathrm{C}_{2}+2 \mathrm{H}_{2} \mathrm{O} \rightarrow 2 \mathrm{LiOH}+\mathrm{C}_{2} \mathrm{H}_{2} \\
& 3 \mathrm{C}_{2} \mathrm{H}_{2} \rightarrow \mathrm{C}_{6} \mathrm{H}_{6} \\
& \text { with } \mathrm{V}_{2} \mathrm{O}_{5} \text { catalyst }
\end{aligned}
$$

The counting source for liquid scintillation spectrometer was prepared by adding a toluene based butyl-PBD scintillation solution to $3.5-4.0 \mathrm{~g}$ of synthesized benzene to a total volume of $20 \mathrm{~mL}$. The synthesized benzene prepared from NIST oxalic acid (SRM 4990C) was used as a standard reference of ${ }^{14} \mathrm{C}$.

Measurement of ${ }^{14} \mathrm{C}$. The ${ }^{14} \mathrm{C}$ activity was measured by a low background liquid scintillation counter, Aloka LB-1, under temperature-stabilized conditions at $12{ }^{\circ} \mathrm{C}$ at least for $100 \mathrm{~min}$ $\times 40$ times. The counting background of the $20 \mathrm{~mL}$ low potassium glass vial was $2.64 \mathrm{cpm}$ at a rate of $58 \%$ efficiency. The results are presented as $\Delta^{14} \mathrm{C}$, defined in the previous paper. ${ }^{9}$ Isotopic fluctuation of a sample was corrected using the $\delta^{13} \mathrm{C}$ value of $-26.4 \%$, which was the average of the $\delta^{13} \mathrm{C}$ values determined for several tree-ring samples with the Finnigan MAT Stable Isotope Ratio Mass Spectrometer, MAT 252.

\section{Results and Discussion}

Concentration of organically-bound ${ }^{14} \mathrm{C}$ in the Shika-sample $\left(37.1^{\circ} \mathrm{N}, 136.5^{\circ} \mathrm{E}\right)$ was measured for the ring-years of 1949 to 1999 and compared with those of the Tatsunokuchi-sample $\left(36.4^{\circ} \mathrm{N}, 136.5^{\circ} \mathrm{E}\right)^{9}$ for the $1941-1987$ period to investigate the regional differences of environmental ${ }^{14} \mathrm{C}$ concentration.

The Shika-sample was grown in a small pine forest at the seaside of Shika-machi situated on a lowland plain area about $20 \mathrm{~m}$ above sea level and lies along the coast of the Sea of Japan; high mountains are not present in the surroundings. On the other hand, Tatsunokuchi-sample was grown at a site halfway down a hill of about $50 \mathrm{~m}$ above sea level near the rim of the high mountain region of 1500-2000 m, located about 70 $\mathrm{km}$ south of Shika-machi. The two sets of sampling sites are shown in Figure 1.

The $\Delta^{14} \mathrm{C}$ values measured for the Shika-sample are given in Table 1. The $\Delta^{14} \mathrm{C}$ values in the table were reproducible at \pm 10

\begin{tabular}{|c|c|c|}
\hline Year & $\Delta^{14} \mathrm{C}^{*} / \% o$ & $\begin{array}{c}\text { Total } \\
\text { counting time/min }\end{array}$ \\
\hline 1999 & $107.0 \pm 4.6$ & 4000 \\
\hline 1998 & $116.7 \pm 4.6$ & 4000 \\
\hline 1997 & $115.7 \pm 5.4$ & 4000 \\
\hline 1996 & $121.4 \pm 5.8$ & 5000 \\
\hline 1995 & $124.3 \pm 4.2$ & 5000 \\
\hline 1994 & $132.2 \pm 3.2$ & 10000 \\
\hline 1993 & $137.7 \pm 3.0$ & 11000 \\
\hline 1992 & $159.0 \pm 4.3$ & 5000 \\
\hline 1991 & $134.3 \pm 4.3$ & 8000 \\
\hline 1990 & $166.6 \pm 4.4$ & 5000 \\
\hline 1989 & $176.7 \pm 4.4$ & 5000 \\
\hline 1988 & $187.1 \pm 4.4$ & 5000 \\
\hline 1987 & $175.9 \pm 4.8$ & 4000 \\
\hline 1986 & $195.9 \pm 3.5$ & 8000 \\
\hline 1985 & $222.7 \pm 4.8$ & 5000 \\
\hline 1984 & $224.6 \pm 5.5$ & 4000 \\
\hline 1983 & $242.4 \pm 5.3$ & 4000 \\
\hline 1982 & $275.7 \pm 5.4$ & 4000 \\
\hline 1981 & $259.3 \pm 5.2$ & 4000 \\
\hline 1980 & $307.2 \pm 6.2$ & 4000 \\
\hline 1979 & $293.2 \pm 6.1$ & 4000 \\
\hline 1978 & $313.1 \pm 5.3$ & 8000 \\
\hline 1977 & $358.1 \pm 4.8$ & 5000 \\
\hline 1976 & $351.0 \pm 4.8$ & 5000 \\
\hline 1975 & $393.1 \pm 5.5$ & 6000 \\
\hline 1974 & $402.1 \pm 5.5$ & 4000 \\
\hline 1973 & $434.2 \pm 5.5$ & 4000 \\
\hline 1972 & $483.2 \pm 5.2$ & 5000 \\
\hline 1971 & $480.5 \pm 3.7$ & 10000 \\
\hline 1970 & $499.4 \pm 3.1$ & 14000 \\
\hline 1969 & $538.7 \pm 3.8$ & 10000 \\
\hline 1968 & $573.6 \pm 6.1$ & 4000 \\
\hline 1967 & $654.2 \pm 6.5$ & 4000 \\
\hline 1966 & $691.9 \pm 6.8$ & 4000 \\
\hline 1965 & $760.7 \pm 6.4$ & 4000 \\
\hline 1964 & $814.0 \pm 6.7$ & 4000 \\
\hline 1963 & $726.9 \pm 6.5$ & 4000 \\
\hline 1962 & $327.2 \pm 4.4$ & 8000 \\
\hline 1961 & $218.0 \pm 3.6$ & 8000 \\
\hline 1960 & $215.7 \pm 4.9$ & 4000 \\
\hline 1959 & $233.0 \pm 5.1$ & 4000 \\
\hline 1958 & $128.1 \pm 2.8$ & 12000 \\
\hline 1957 & $235.9 \pm 3.7$ & 8000 \\
\hline 1956 & $38.0 \pm 4.6$ & 4000 \\
\hline 1955 & $-2.6 \pm 4.4$ & 4000 \\
\hline 1954 & $-17.6 \pm 4.3$ & 4000 \\
\hline 1953 & $-28.7 \pm 4.6$ & 4000 \\
\hline 1952 & $-42.3 \pm 2.8$ & 9000 \\
\hline 1951 & $-35.9 \pm 3.8$ & 5000 \\
\hline 1950 & $-33.9 \pm 3.6$ & 4000 \\
\hline 1949 & $-44.4 \pm 4.3$ & 4000 \\
\hline
\end{tabular}
$\% \circ$ or less, as described in the previous paper. ${ }^{9}$
TABLE 1: Carbon-14 Concentration in Tree-ring Cellulose of a Pine Tree in Shika-machi, Ishikwa Prefecture, Japan $\left(37.1^{\circ} \mathrm{N}, 136.5^{\circ} \mathrm{E}\right)$

*The error denotes a counting error of $1 \sigma$.

All samples were measured using a low background liquid scintillation counter, Aloka LB-1. 


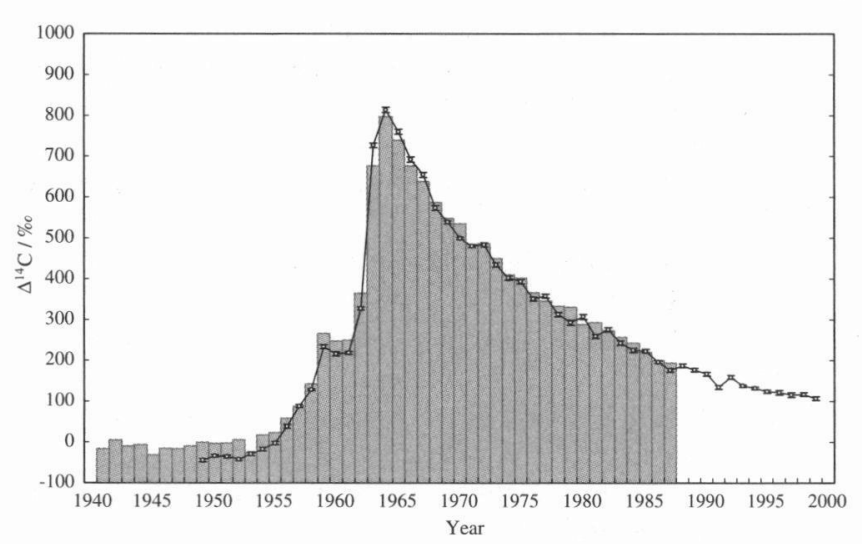

Figure 2. Annual variation of the $\Delta^{14} \mathrm{C}$ values of the Shika-sample and Tatsunokuchi-sample.

The bar graph: Tatsunokuchi-sample

O: Shika-sample

The annual variation of $\Delta^{14} \mathrm{C}$ values of the Shika- and the Tatsunokuchi-sample are plotted as a function of the ring-year in Figure 2. Temporal variation of organically-bound ${ }^{14} \mathrm{C}$ concentration in the Shika-sample showed essentially similar variations to that of the Tatsunokuchi-sample. The $\Delta^{14} \mathrm{C}$ value of both the Shika- and the Tatsunokuchi-sample began to increase from 1954 to a small broad peak of $250 \%$ in 1959-1961, followed by a rapid increase to the highest value of approximately $800 \%$ in 1964 . After the maximum, it diminished gradually year by year during past two or three decades. However, it demonstrated a small difference in the amplitude of the $\Delta^{14} \mathrm{C}$ value during the period of 1949-1967, 1970, and 1978-1981. After 1982, significant difference was not observed between the two sets of samples. These differences suggest that the ${ }^{14} \mathrm{C}$ concentration in atmospheric $\mathrm{CO}_{2}$ fluctuated even in the narrow region only by about $70 \mathrm{~km}$ of distance for the period before 1982. It is assumed that the ${ }^{14} \mathrm{C}$ records in a series of annual rings of the tree reflect the variation of annual average levels of ${ }^{14} \mathrm{C}$ concentration in atmospheric $\mathrm{CO}_{2}$ at the growth site of the tree, since the carbon necessary for synthesizing cellulose is derived essentially by photosynthesis from the $\mathrm{CO}_{2}$ in the air.

In Figure 3, the annual variation of $\Delta^{14} \mathrm{C}$ values obtained from the Shika-sample is compared with those of $\Delta^{14} \mathrm{C}$ values in tree rings from East Asia region reported by other researchers, for a spruce from Dailing, China $\left(47^{\circ} \mathrm{N}, 129^{\circ} \mathrm{E}\right){ }^{7}$ for red pines from Mt. Chiak $\left(37^{\circ} 23^{\prime} \mathrm{N}, 128^{\circ} 3^{\prime} \mathrm{E}\right.$ and $\left.37^{\circ} 20^{\prime} \mathrm{N}, 128^{\circ} 4^{\prime} \mathrm{E}\right)$ and Mt. Kyeryong ( $\left.36^{\circ} 20^{\prime} \mathrm{N}, 127^{\circ} 13^{\prime} \mathrm{E}\right)$, Korea, ${ }^{13}$ and for Japanese cypress from Kiso mountainous district, Gifu prefecture, Japan $\left(35.6^{\circ} \mathrm{N}, 137.5^{\circ} \mathrm{E}\right) .^{6}$

An interesting result in comparing our data with those of other researchers is that there existed significant difference in the amplitude of the $\Delta^{14} \mathrm{C}$ value during the period of 1963-1967. The disagreement of the $\Delta^{14} \mathrm{C}$ value among trees during the period of 1963-1967 can be interpreted by the so-called latitude dependence of the ${ }^{14} \mathrm{C}$ variations in the northern troposphere, ${ }^{6-7}$ which was due to the ${ }^{14} \mathrm{C}$ released to the atmosphere at higher northern latitudes by a series of thermonuclear detonations carried out during the early 1960 s.

The most important result in this work is that the difference of $\Delta^{14} \mathrm{C}$ values was found during the period of 1970-1981 between our data and those of other reports. The spruce from Dailing, China, located in higher latitude than Shika-machi, showed higher $\Delta^{14} \mathrm{C}$ values than our pine tree. The red pines from Mt. Chiak and Mt. Kyeryong, Korea, located at almost the same latitude of Shika-machi, showed slightly lower $\Delta^{14} \mathrm{C}$ values than our pine tree. On the contrary, the $\Delta^{14} \mathrm{C}$ values of Japanese cypress from Kiso mountainous district, Gifu prefecture, Japan, coincided with those of our pine tree, except for the period of 1976 and 1980-1981.

On the basis of these results, it was found that the ${ }^{14} \mathrm{C}$ concen-

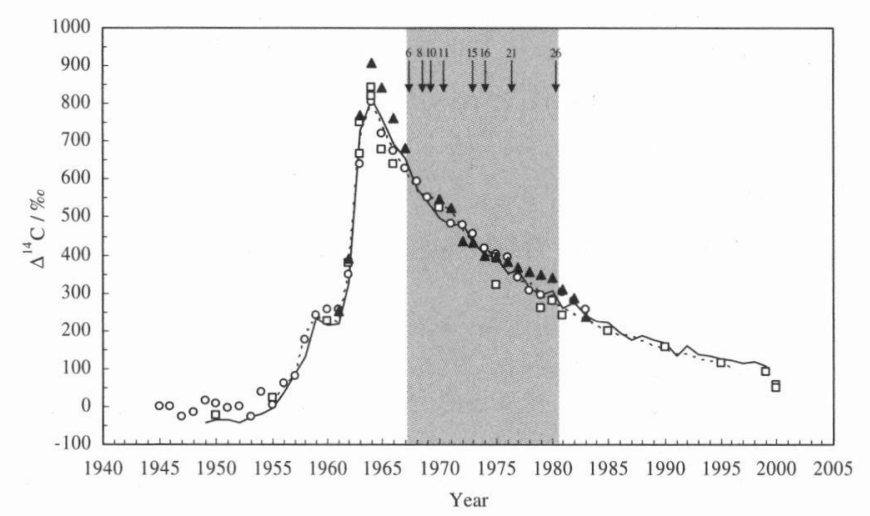

Figure 3. Comparison of annual variation of $\Delta^{14} \mathrm{C}$ values in tree rings from different sites. Arrows and numerals at the top of the figure represent the number and time of year of the Chinese thermonuclear bomb test.

The solid line: pine tree in this work $\left(37.1^{\circ} \mathrm{N}, 136.5^{\circ} \mathrm{E}\right)$

A: spruce from Dailing, China $\left(47^{\circ} \mathrm{N}, 129^{\circ} \mathrm{E}\right)$, by D. Kaimei et al.

$\square$ : red pines from Mt. Chiak ( $37^{\circ} 23^{\prime} \mathrm{N}, 128^{\circ} 3^{\prime} \mathrm{E}$ and $37^{\circ} 20^{\prime} \mathrm{N}$, $\left.128^{\circ} 4^{\prime} \mathrm{E}\right)$ and Mt. Kyeryong ( $\left.36^{\circ} 20^{\prime} \mathrm{N}, 127^{\circ} 13^{\prime} \mathrm{E}\right)$, Korea, by J. H. Park et al. ${ }^{13}$

$\mathrm{O}$ : Japanese cypress from Kiso mountainous district, Gifu prefecture, Japan $\left(35.6^{\circ} \mathrm{N}, 137.5^{\circ} \mathrm{E}\right)$, by T. Nakamura et al. ${ }^{6}$

The dotted line: compiled atmospheric ${ }^{14} \mathrm{C}$ curve for the northern hemisphere temperate region by Q. Hua and M. Barbetti ${ }^{3}$

tration in atmospheric $\mathrm{CO}_{2}$ was considerably disturbed during the period of 1970-1981, especially in 1970, 1976, and 19781981, in the East Asia region. However, for the period from 1970 onwards, it is known that there has not been much difference between locations in terms of the ${ }^{14} \mathrm{C}$ concentration in atmospheric $\mathrm{CO}_{2}$ in the Northern Hemisphere, since the bomb ${ }^{14} \mathrm{C}$ reached a global equilibrium in the late $1960 \mathrm{~s} .{ }^{1-3}$ Compiled atmospheric ${ }^{14} \mathrm{C}$ curve for the northern hemisphere temperate region by $\mathrm{Hua}$ and $\mathrm{Barbetti}^{3}$ is shown by the dotted line in Figure 3 . Their average yearly atmospheric $\Delta^{14} \mathrm{C}$ values agreed well with our data except the period of 1970 and 19781981, whereas, they disagreed with the data of 1976-1982 rings of the spruce from Dailing, China. It was pointed out by Kaimei et al. ${ }^{7}$ that excessive ${ }^{14} \mathrm{C}$ in the $1976-1982$ rings of the spruce from Dailing, China, was likely due to the effect of 1976 and 1980 Chinese bomb tests.

After the Partial Test Ban Treaty of 1963, nuclear tests in the atmosphere declined greatly, however, the People's of Republic of China continued atmospheric nuclear test until 1980. Bomb ${ }^{14} \mathrm{C}$ is produced in the nuclear reaction between thermal neutrons delivered in the explosion and nitrogen in the air. About 7 times larger amounts of thermal neutron are released by the thermonuclear explosion than by the atomic explosion. Thus, the time of year of the Chinese thermonuclear bomb tests are shown by arrows in Figure 3. The Chinese thermonuclear bomb tests were conducted 8 times, namely the 6th (June, 1967), 8th (December, 1968), 10th (September, 1969), 11th (October, 1970), 15th (June, 1973), 16th (June, 1974), 21st (November, 1976), and 26th (October, 1980). ${ }^{4}$

It is apparent from these considerations that the disturbance of the ${ }^{14} \mathrm{C}$ concentration in atmospheric $\mathrm{CO}_{2}$ occurred during the period of 1970-1981 in the East Asia region may be interpreted by the possibility of the several times of injections of ${ }^{14} \mathrm{C}$ originated from a series of Chinese thermonuclear bomb tests. This assumption was supported by the fact that the $\Delta^{14} \mathrm{C}$ values from three distinct sites in the East Asia region agreed well with each other after 1982, when the Chinese thermonuclear bomb tests were suspended.

Acknowledgments. The authors wish to express their thanks to Dr. Hikaru Amano and Dr. Mariko Andoh, Japan Atomic Energy Research Institute, for their helpful advice in 
our mass spectrometer analyses. This study was supported in part by a Grant from the Ishikawa Prefectural Institute of Public Health and Environmental Science.

\section{References}

(1) E. M. Druffel and H. E. Suess, J. Geophys. Res. 88, 1271 (1983).

(2) I. Levin, Radiocarbon 46, 1261 (2004).

(3) Q. Hua and M. Barbetti, Radiocarbon 46, 1273 (2004).

(4) Y. Katsuragi, K. Kawamura, and H. Inoue, Pap. Met. Geophys. 34, 21 (1983).

(5) W. F. Cain and H. E. Suess, J. Geophys. Res. 81, 3688 (1976).

(6) T. Nakamura, N. Nakai, M. Kimura, S. Ohishi, Y. Hattori, and Y. Kikata, Chikyu Kagaku 21, 7 (1987) (in Japanese).

(7) D. Kaimei, Q. Youneng, and C. Y. Fan, Radiocarbon 34, 753 (1992).
(8) I. U. Olsson and G. Possnert, Radiocarbon 34, 757 (1992).

(9) Y. Yamada, K. Yasuike, M. Itoh, N. Kiriyama, K. Komura, and K. Ueno, J. Radioanal. Nucl. Chem. 227, 37 (1998).

(10) Y. Muraki, G. Kocharov, T. Nishiyama, Y. Naruse, T. Murata, K. Masuda, and Kh. A. Arslanov, Radiocarbon 40, 177 (1998).

(11)I. Krajcar-Bronić, N. Horvatinčić, and B. Obelić, Radiocarbon 40, 399 (1998).

(12) A. Z. Rakowski, S. Pawełczyk, and A. Pazdur, Radiocarbon 43, 679 (2001).

(13) J. H. Park, J. C. Kim, M. K. Cheoun, I. C. Kim, M. Youn, Y. H. Liu, and E. S. Kim, Radiocarbon 44, 559 (2002).

(14) Y. Yamada, K. Yasuike, and K. Komura, J. Radioanal. Nucl. Chem. 262, 679 (2004).

(15) Y. Yamada, M. Itoh, N. Kiriyama, C. Nishimoto, K. Komura, and K. Ueno, J. Radioanal. Nucl. Chem. Articles 130, 169 (1989). 